\section{Plasma and tissue clindamycin antimicrobial activity after parenteral administration to cats under surgical conditions}

\author{
Sabrina Passini, ${ }^{1}$ Laura Montoya, ${ }^{1}$ \\ Martín Lupi, ${ }^{1}$ Paula Lorenzini, ${ }^{1}$ \\ María Fabiana Landoni,2 \\ Gabriela Albarellos ${ }^{1}$
}

1 Universidad de Buenos Aires, Facultad

de Ciencias Veterinarias, Cátedra de

Farmacología; 2Universidad Nacional de

La Plata, Facultad de Ciencias

Veterinarias, Cátedra de Farmacología,

Buenos Aires, Argentina

\begin{abstract}
Clindamycin plasma and tissue disposition in cats under surgical conditions after a single intravenous (IV), intramuscular (IM) and subcutaneous (SC) administration at a dose rate of $10 \mathrm{mg} / \mathrm{kg}$ were studied. After intravenous, intramuscular and subcutaneous administration, peak plasma concentrations were $10.93 \pm 3.78 \mu \mathrm{g} / \mathrm{mL}\left(\mathrm{C}_{\mathrm{p}(0)}\right)$, $5.93 \pm 1.18 \mu \mathrm{g} / \mathrm{mL}\left(\mathrm{C}_{\max }\right)$ and $6.30 \pm 0.88$ $\mu \mathrm{g} / \mathrm{mL}\left(\mathrm{C}_{\max }\right)$, respectively. Eight hours after clindamycin IV, IM and SC administration plasma concentrations declined to $2.01 \pm 0.61 \mu \mathrm{g} / \mathrm{mL}, 2.96 \pm 0.43 \mu \mathrm{g} / \mathrm{mL}$ and $3.36 \pm 0.97 \mu \mathrm{g} / \mathrm{mL}$, respectively. Sixty to 90 minutes after clindamycin administration, tissue concentrations ranged from a minimum in subcutaneous tissue of $4.90 \mu \mathrm{g} / \mathrm{g}$ (IV), $3.06 \mu \mathrm{g} / \mathrm{g}$ (IM) and, $3.13 \mu \mathrm{g} / \mathrm{g}$ (SC) to a maximum in uterus of $13.41 \mu \mathrm{g} / \mathrm{g}$ (IV), $14.07 \mu \mathrm{g} / \mathrm{g}$ (IM) and, $14.44 \mu \mathrm{g} / \mathrm{g}$ (SC). The lowest tissue/plasma concentration ratio for the three administration routes was observed in subcutaneous tissue, while the highest was observed at genital level (ovary for IV and IM and uterus for SC). Estimated efficacy predictor (AUC/MIC), considering MIC breakpoint for bacteria isolated from animals, indicates that clindamycin administered IV, IM or SC at the studied dose is appropriated for perioperative prophylactic protocols and that given with a dose interval of 12 hours would be effective for susceptible infection treatment in cats.
\end{abstract}

\section{Introduction}

Clindamycin is a lincosamide antibiotic more active than lincomycin. It is a basic compound with a pKa of 7.6 and high lipid solubility. It has wide distribution and large tissue penetration. It can be administered by both oral and parenteral routes, being metabolized in liver to active (N-dimethyl clindamycin and clindamycin sulfoxide) and inactive (glucuronide) metabolites which are eliminated through bile and urine. 1-3 Clindamycin antibacterial spectrum includes gram-positive cocci (Staphylococcus spp., streptococci betahemolytic group), anaerobic bacteria, mycoplasma and many protozoa (Toxoplasma gondii).4,5 Minimum inhibitory concentration (MIC) breakpoint for bacteria isolated from animals has been set in $\leq 0.5 \mu \mathrm{g} / \mathrm{mL} .{ }^{6}$ According to their bacterial killing kinetics, lincosamides are classified as time-dependent with moderate to prolonged persistent effects. The ideal dosing regimen for these antibiotics maximizes the amount of drug received. Therefore, the $\mathrm{AUC}_{(0-24)} / \mathrm{MIC}$ ratio is the parameter that correlates with efficacy. Maximum killing is seen when $\mathrm{AUC}(0-24) / \mathrm{MIC}$ is $25-35.7-10$

Clindamycin has many therapeutic indications in small animal veterinary medicine. The main indications are infections caused by Gram-positive aerobic bacteria, including staphylococcal infections, streptococcal toxic shock syndrome and diseases caused by anaerobic microorganisms, in penicillinhypersensitive patients. It is also highly indicated for many soft tissue infections as well as periodontal disease and osteoarticular infections. It could be used as monodrug therapy or, for the treatment of serious life-threatening infections (sepsis, peritonitis, osteomyelitis), in combined protocols. It is also indicated for antibiotic prophylaxis in some clean-contaminated and contaminated surgical wounds.4,5,11,12 In spite of its good oral absorption and bioavailability, parenteral dosing is preferred for the treatment of serious infections and prophylaxis of surgical wound infections. In such situations, recommended dosage scheme is 5-30 $\mathrm{mg} / \mathrm{kg}$ every $12-24$ hours. $4,13-15$

There are few reports of clindamycin plasma pharmacokinetics and tissue disposition in dogs and cats. Lavy et al. ${ }^{16}$ described clindamycin pharmacokinetics in dogs after intravenous (IV), intramuscular (IM) and, subcutaneous (SC) administration and Batzias et al. ${ }^{17}$ oral bioavailability in the same species. Clindamycin pharmacokinetics in cats has been described only after oral administration. ${ }^{18-20}$ However, to the authors' knowledge there are no reports characterizing neither plasma nor tissue disposition after parenteral administration. So, the aim of the present study is to describe clindamycin disposition in plasma and in some selected tissues after single IV, IM and SC administration to cats.
Correspondence: Gabriela Albarellos, Universidad de Buenos Aires, Facultad de Ciencias Veterinarias, Cátedra de Farmacología, Chorroarín 280 (1427), Buenos Aires, Argentina.

E-mail: albarell@fvet.uba.ar

Key words: antimicrobials; clindamycin; plasma concentrations; tissue concentrations; cats.

Acknowledgments: this work was supported by a grant (Research Project UBACyT 20020130100400, 2014-2017) of Secretaría de Ciencia y Técnica, Universidad de Buenos Aires, Argentina. The authors are indebted to Purina ProPlan, Argentina for the kind provision of animal food.

Contributions: the authors contributed equally.

Received for publication: 1 December 2015. Accepted for publication: 18 December 2015.

This work is licensed under a Creative Commons Attribution NonCommercial 4.0 License (CC BY-NC 4.0).

(C) Copyright S.Passini et al., 2017

Licensee PAGEPress srl, Italy

Veterinary Science Development 2017; 7:6341 doi:10.4081/vsd.2017.6341

\section{Materials and Methods}

\section{Experimental animals}

Experimental animals were twenty-three young (1-2 years old) mixed-breed cats with an average weight of $3.18 \pm 0.58 \mathrm{~kg}$. All cats were healthy as determined by clinical examination, complete blood and serum biochemical analysis and urinalysis. Animals were client-owned cats presented for standard surgical procedures of ovariectomy or orchiectomy. All animal handlings were approved by the Institutional Animal Care and Use Committee, School of Veterinary Science, University of Buenos Aires, Argentina.

\section{Dosage form}

An aqueous $15 \%$ clindamycin phosphate salt solution (Clindamicina Richet ${ }^{\circledR}$, Richet, Buenos Aires, Argentina) was used. Clindamycin was administered at a dose rate of $10 \mathrm{mg} / \mathrm{kg}$ intravenously (cephalic vein), over a 2 minute period, to 11 cats ( 8 females and 4 males), intramuscularly (dorsal lumbar muscles) to six cats (6 females) and subcutaneously (lateral ribcage skin) to six cats ( 5 females and one male).

\section{Experimental design}

A prospective randomized study was designed. Prior starting the study, two 
catheters (Jelco ${ }^{\circledR}, \quad$ Smith Medical International Ltd., Italy) were placed into the cephalic veins. One of them (24G), was for antibiotic and fluid $(\mathrm{NaCl} 0.9 \%, 10$ $\mathrm{mL} / \mathrm{kg} / \mathrm{h}$ ) administration; and, the other (22G), for blood sample withdrawal.

Surgical procedures (ovariectomy or orchidectomy) were performed according to conventional standard techniques under general parenteral anaesthesia (midazolam $0.2 \mathrm{mg} / \mathrm{kg}$, Midazolam ${ }^{\circledR}$, Richmond Vet Pharma, Argentina; ketamine $10 \mathrm{mg} / \mathrm{kg}$, Ketonal $100^{\circledR}$, Richmond Vet Pharma, Argentina; xylazine $0.5 \mathrm{mg} / \mathrm{kg}$, Rompun ${ }^{\circledR}$, Bayer S.A., Argentina). Clindamycin was administered IV, IM or SC 1-1.5 hours prior first surgical incision.

\section{Blood sampling}

Blood samples $(0.7 \mathrm{~mL})$ were collected with a heparinised syringe at $0.08 ; 0.16$; $0.33 ; 0.50 ; 0.75 ; 1 ; 1.50 ; 2 ; 3 ; 4 ; 6$ and 8 hours after clindamycin administration.

Samples were centrifuged at $1500 \times \mathrm{g}$, for $15 \mathrm{~min}$, and then plasma was harvested and stored at $-20^{\circ} \mathrm{C}$ until analysis.

\section{Tissue sampling}

Tissue samples (0.1-0.5 g) were taken at 1-1.5 hours after clindamycin administration. Selected tissues/organs were skin, subcutaneous tissue, muscle, ovary, uterus, testicle and epididymis. Samples were rinsed briefly with saline solution and dried through gentle pressure with sterile gauze for removing blood contamination. Then, they were weighed and stored at $-20^{\circ} \mathrm{C}$.

Clindamycin was eluted from tissue samples following a technique described by Bamberg et al. ${ }^{21}$ Briefly, samples were cut into small pieces and diluted with phosphate buffer $\mathrm{pH} 7$ (in a ratio 1:2 w/v) and incubated for $24 \mathrm{~h}$ at $4^{\circ} \mathrm{C}$, applying agitation during the first $40 \mathrm{~min}$ of incubation. Finally, they were centrifuged (1500 $\mathrm{g}$ for $15 \mathrm{~min}$ ) and the supernatant harvested till assayed. All collected samples (plasma and tissue) were assayed within two weeks after collection.

\section{Plasma and tissue drug analysis}

Clindamycin plasma and tissue concentrations were determined by microbiological assay,22 using Kocuria rhizophila ATCC 9341 as test microorganism. Standard curves were prepared on normal cat plasma and phosphate buffer $\mathrm{pH} 7$, depending on the sample matrix to be quantified Each sample was seeded in triplicate and each standard dilution in quintuplicate. Limit of detection and quantification of the method was $0.78 \mu \mathrm{g} / \mathrm{mL}$. The method was linear between 0.39 and $50 \mu \mathrm{g} / \mathrm{mL}(\mathrm{r}=0.9985)$. Inter and intra-assay coefficients of variation were less than $10 \%$.

\section{Pharmacokinetic parameters}

Reported pharmacokinetic parameters were determined using standard noncompartmental analysis (Phoenix ${ }^{\circledR}$ WinNonlin ${ }^{\circledR}$ 6.3, 2005-2012, Certara, L.P.) The areas under the concentration versustime curves from time zero to time of last sampling time $\left(\mathrm{AUC}_{0-\mathrm{t}} \mathrm{t}\right)$ were calculated using a combination of the linear and logarithmic trapezoidal rules. Values for maximum concentration $\left(\mathrm{C}_{\max }\right)$ and time to $\mathrm{C}_{\max }$ $\left(\mathrm{T}_{\max }\right)$ were determined visually from the graphs.

\section{Statistical analysis}

Pharmacokinetic parameters, tissue concentrations and, tissue/plasma ratios are reported as mean \pm standard deviation (SD).

Area under plasma concentration vs time $\left(\mathrm{AUC}_{(0-\mathrm{t})}\right)$, last measured plasma concentration, tissue concentrations and, tissue/plasma ratios after for the three administration routes were statistically compared applying ANOVA followed by Tukey. Peak concentration $\left(\mathrm{C}_{\max }\right)$ and $\mathrm{T}_{\max }$ were compared using Student's t test. Differences were considered significant when $\mathrm{P}<0.05$.

\section{Results}

Adverse effects were not observed during or after IV, IM or SC clindamycin administration in any of the cats. Mean plasma concentration vs time curves for the three studied routes are given in Figure 1 and the correspondent pharmacokinetic parameters in Table 1. Clindamycin plasma disposition after IM and SC administration was rather similar; however, administered IM clindamycin seems to be absorbed faster as reflected by the shorter $\mathrm{T}_{\max }(\mathrm{P}<0.05)$.

Plasma concentrations of clindamycin were above the limit of detection for up to 8 hours for the three administration routes. However, at this time, extravascular administration routes lead to significant higher concentrations $\quad(2.01 \pm 0.61 \mu \mathrm{g} / \mathrm{mL}$, $2.96 \pm 0.43 \mu \mathrm{g} / \mathrm{mL}$ and $3.36 \pm 0.97 \mu \mathrm{g} / \mathrm{mL}$, for IV, IM and SC, respectively).

Clindamycin tissue concentration and tissue/plasma concentration ratios are shown in Table 2. For most of the studied tissues, tissue/plasma ratios were above 1, reflecting clindamycin wide tissue penetration. Exception for the three studied administration routes was the subcutaneous tissue.

Extravascular routes showed, compared to the IV route, lower ratios; for both routes, ratio lower than 1 was observed for skin, subcutaneous tissue and muscle. A lower than 1 ratio was observed for testicles and epididymis after SC administration.

\section{Discussion}

Parenteral administration of clindamycin is frequently used in cats for the prophylaxis of surgical wound infections and, also for the treatment of serious infections. However, in this species there are not reports on clindamycin plasma or tissue disposition after parenteral administration. The present study is a contribution to the knowledge of clindamycin pharmacology because it describes plasma and some tissue clindamycin concentration after IV, IM and SC administration to cats. It is important to highlight that the present study has some weaknesses. First, related to analytical method used for clindamycin quantification. Since microbiological assay cannot distinguish between clindamycin and its active metabolites (clindamycin sulfoxide and N-dimethyl clindamycin) reported concentrations actually represent total clindamycin antimicrobial activity. On the other hand, restricted blood sampling period do not allowed an integral pharmacokinetic description. It is important to highlight that the applied experimental design was done under genuine standard surgical procedures (ovariectomies and orchidectomy). Therefore, tissue samples were limited to some soft tissues, representatives of different degree of tissue perfusion at a fixed time point (1-1.5 $\mathrm{h}$ post-administration). This was a disadvantage because it did not allow knowing or predicting later tissue concentrations. However, previous reports indicate that for macrolides and lincosamides tissue concentrations decline in parallel with plasma concentrations.23,24 After extravascular administration, clindamycin was rapidly absorbed. Intramuscular administration showed the shortest $T_{\max }$, implying the fastest absorption. This finding is not unexpected, based on the higher irrigation of muscles compare to subcutaneous space. No differences were observed on $\mathrm{C}_{\max }$, reflecting that, with temporal differences, both administration routes reach the same drug level. Slightly lower $\mathrm{C}_{\max }$ (4.4 vs 5.93 $\mu \mathrm{g} / \mathrm{mL})$ and longer $\mathrm{T}_{\max }(1.22$ vs $1.00 \mathrm{~h})$ have been reported in dogs after IM administration. 16 On the contrary, after SC administration to dogs, reported $\mathrm{C}_{\max }$ are much higher $(20.8$ vs. $6.30 \mu \mathrm{g} / \mathrm{ml})$ and $\mathrm{T}_{\max }$ shorter $(0.78$ vs $1.13 \mathrm{~h})$ than in cats. ${ }^{16}$ Clindamycin plasma disposition curves after the three administration routes were very similar as reflected by their similar $\mathrm{AUC}_{(0-\mathrm{t})}$ values. Also, plasma concentrations were well above MIC breakpoint $(0.5$ $\mu \mathrm{g} / \mathrm{mL}$ ) even at the last sampling time. At this time higher concentrations were observed for the IM and SC routes, clearly 
reflecting the absorption process and suggesting that, compared to IV, extravascular clindamycin administrations could allow longer dose intervals.

The AUC/MIC ratio estimated for the three studied administration routes was well above the value associated with maximum killing (25-35), 7-10 allowing to predict that clindamycin administered IV, IM or SC at a dose rate of $10 \mathrm{mg} / \mathrm{kg}$ will be highly effective. In the present study, clindamycin concentrations in all the sampled tissues were always higher than bacterial MIC breakpoint. The higher clindamycin tissue concentrations were observed after IV administration; statistical differences between the three administration routes were detected only for skin. For most of the studied tissues, plasma/tissue ratios were above 1, reflecting clindamycin wide tissue penetration. Exception for the three studied administration routes was the subcutaneous tissue. Similar ratios have been reported by Brown et al. 20 after multiple oral clindamycin dosage to cats. This scenario is not unexpected considering the high lipophilicity of clindamycin.

Extravascular routes showed, compared to the IV route, lower ratios; not unexpected due to the higher concentration gradient achieved after intravenous administration. For both routes plasma/tissue ratios lower than 1 were observed for skin, subcutaneous tissue and muscle. The observed differences between tissues can be attributed to anatomical and physiologic tissue particularities (such as composition, tissue blood perfusion rate, etc.).

\section{Conclusions}

The present results suggest that clindamycin administered by IV, IM or SC route in cats at a dose rate of $10 \mathrm{mg} / \mathrm{kg}$

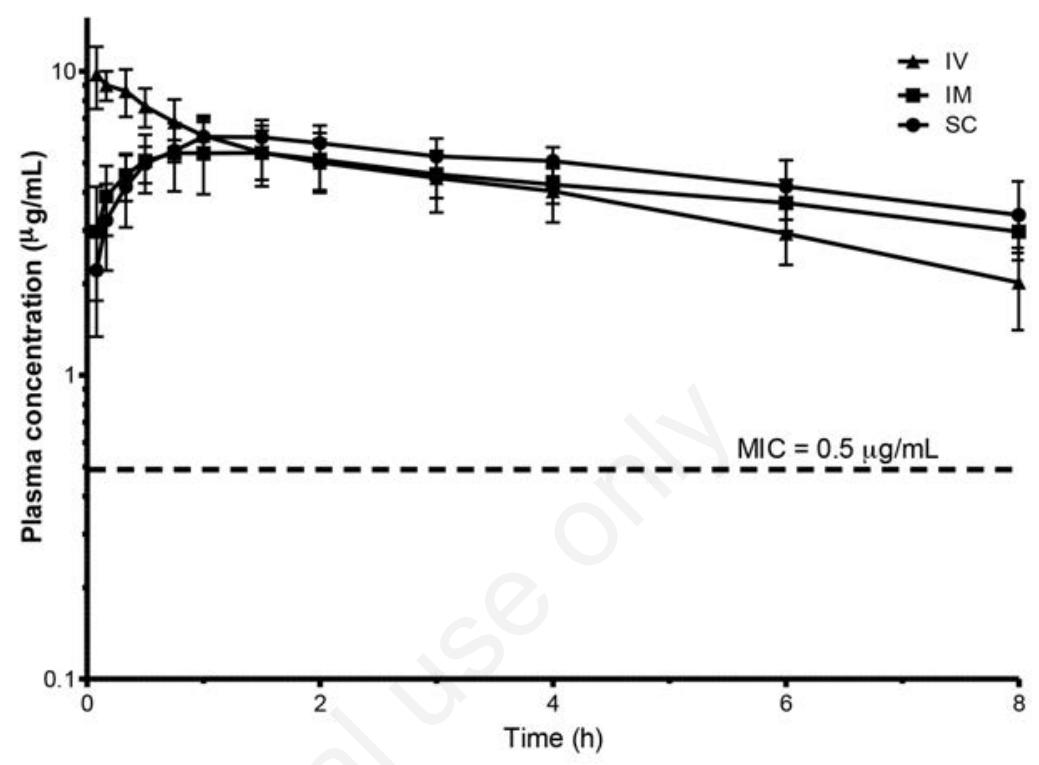

Figure 1. Mean $( \pm$ SD) clindamycin plasma concentration-time profile after IV $(\Delta)$, IM ( a) and SC $(\bullet)$ administration to cats at a dose of $10 \mathrm{mg} / \mathrm{kg}$. MIC value corresponds to Staphylococcus spp. MIC breakpoint for veterinary pathogens (MIC $\leq 0.5 \mu \mathrm{g} / \mathrm{mL}$ ).

Table 1. Pharmacokinetic parameters $($ mean \pm SD) of clindamycin after intravenous, intramuscular and subcutaneous administration to cats at a dose rate of $10 \mathrm{mg} / \mathrm{kg}$.

\begin{tabular}{lccc}
$\mathrm{AUC}(0-\mathrm{t})(\mu \mathrm{g} . \mathrm{h} / \mathrm{mL})$ & $32.06 \pm 5.55$ & $33.72 \pm 5.24$ & $36.67 \pm 6.49$ \\
$\mathrm{Cp}(0)(\mu \mathrm{g} / \mathrm{mL})$ & $10.93 \pm 3.78$ & - & - \\
\hline $\mathrm{Cmax}(\mu \mathrm{g} / \mathrm{mL})$ & - & $5.93 \pm 1.18$ & $6.30 \pm 0.88$ \\
$\operatorname{Tmax}(\mathrm{h})$ & - & $1.00 \pm 0.38$ & $1.13 \pm 0.31^{*}$ \\
\hline $\mathrm{AUC}(0-\mathrm{t}) / \mathrm{MIC}$ & $64.12 \pm 11.10$ & $67.45 \pm 10.49$ & $73.33 \pm 12.98$ \\
\hline
\end{tabular}

$\mathrm{AUC}_{(0-\mathrm{t})}$ area under the plasma concentration vs time curve from 0 to the last sampling time; $\mathrm{C}_{\mathrm{p}(0)}$ plasma concentration at 0 time; $\mathrm{C}_{\max }$ maximum plasma concentration; $\mathrm{T}_{\max }$ time of maximum plasma concentration; MIC minimum inhibitory concentration. *Significant differences $(\mathrm{P} \leq 0.05)$.

Table 2. Clindamycin tissue concentrations (mean $\pm \mathrm{SD})$ taken between 1-1.5 h after clindamycin administration and, tissue/plasma concentration ratio after IV, IM and SC administration $(10 \mathrm{mg} / \mathrm{kg})$ to cats.

\begin{tabular}{|c|c|c|c|c|c|c|}
\hline Tissue & $\begin{array}{l}\text { IV tissue } \\
\text { concentration } \\
(\mathrm{\mu g} / \mathrm{g})(\mathrm{n})\end{array}$ & $\begin{array}{l}\text { IV tissue/plasma } \\
\text { concentration } \\
\text { ratio }\end{array}$ & $\begin{array}{l}\text { IM tissue concentration } \\
(\mu \mathrm{g} / \mathrm{g}) \\
(\mathrm{n})\end{array}$ & $\begin{array}{l}\text { IM tissue/plasma } \\
\text { concentration } \\
\text { ratio }\end{array}$ & $\begin{array}{c}\text { SC tissue } \\
\text { concentration } \\
(\mu \mathrm{g} / \mathrm{g})(\mathrm{n})\end{array}$ & $\begin{array}{c}\text { SC tissue/plasma } \\
\text { concentration } \\
\text { ratio }\end{array}$ \\
\hline Skin ${ }^{\mathrm{a}}$ & $9.45 \pm 3.15(11)$ & $1.64 \pm 0.39$ & $4.76 \pm 2.73(6)$ & $0.91 \pm 0.52$ & $4.22 \pm 2.50(6)$ & $0.68 \pm 0.37$ \\
\hline Subcutaneous & $4.90 \pm 2.96(8)$ & $0.81 \pm 0.39$ & $3.06 \pm 2.60(4)$ & $0.47 \pm 0.48$ & $3.13 \pm 3.30(5)$ & $0.55 \pm 0.56$ \\
\hline Muscle & $8.15 \pm 3.75(7)$ & $1.36 \pm 0.47$ & $3.78 \pm 3.02(6)$ & $0.67 \pm 0.48$ & $4.95 \pm 2.64(3)$ & $0.80 \pm 0.47$ \\
\hline Ovary & $12.10 \pm 5.37(14)$ & $2.38 \pm 0.77$ & $13.28 \pm 8.47(12)$ & $2.46 \pm 1.53$ & $11.25 \pm 5.76(10)$ & $1.96 \pm 1.01$ \\
\hline Uterus & $13.41 \pm 2.02(7)$ & $1.96 \pm 0.80$ & $14.07 \pm 2.43(6)$ & $2.23 \pm 1.41$ & $14.44 \pm 3.11(3)$ & $2.15 \pm 0.85$ \\
\hline Testicle & $9.61 \pm 4.26(6)$ & $1.68 \pm 0.67$ & - & - & $3.96 \pm 0.11(2)$ & $0.57 \pm 0.02$ \\
\hline Epididymis & $9.59 \pm 3.26(6)$ & $1.67 \pm 0.47$ & - & - & $5.00 \pm 0.49(2)$ & $0.71 \pm 0.07$ \\
\hline
\end{tabular}

aSignificant differences between clindamycin skin concentrations and between skin/plasma concentrations rate after intravenous vs. extravascular administrations. 
reach concentrations in plasma and tissues well above of bacterial MIC breakpoint $(0.5$ $\mu \mathrm{g} / \mathrm{mL}$ ), with and AUC/MIC twice that reported as optimal for maximal bacterial killing. Therefore, it will be highly effective for the prophylaxis of surgical wound infection and for preventing bacteria colonization in abdominal surgery. Also, for treatment of serious infections $10 \mathrm{mg} / \mathrm{kg} / 12 \mathrm{~h}$ would be highly effective.

\section{References}

1. Sun FF, His PSP. Metabolism of clindamycin I: absorption and excretion of clindamycin in rat and dog. J Pharm Sci 1973;62:1265-9.

2. Sun FF. Metabolism of clindamycin II: urinary excretion products of clindamycin in rat and dog. J Pharm Sci 1973;62:1657-62.

3. Wynalda MA, Hutzler JM, Koets MD, et al. In vitro metabolism of clindamycin in human liver and intestinal microsomes. Drug Metab Dispos 2003; 31:878-87.

4. Greene C. Infectious diseases of the dog and cat. 4th ed. St Louis: Elsevier; 2012. pp 1236-1237.

5. Giguère S. Lincosamides, pleuromutilins, and streptogramins. In: Giguère $S$, Prescott JF, Dowling PM, eds. Antimicrobial therapy in veterinary medicine. 5th ed. Ames: Wiley Blackwell; 2013. pp 199-210.

6. Clinical and Laboratory Standards Institute. Performance Standards for Antimicrobial Disk and Dilution Susceptibility Test for Bacteria Isolated from Animals; Second Informational
Supplement CLSI document VET01S2. Wayne (PA), USA; 2013.

7. Finberg RW, Guharoy R. Clinical use of anti-infective agents: a guide on how to prescribe drugs used to treat infections. New York: Springer; 2012. pp 5-14.

8. Martinez MN, Papich MG, Drusano GL. Dosing regimen matters: the importance of early intervention and rapid attainment of the pharmacokinetic/pharmacodynamic target. Antimicrob Agents Chemother 2012;56:2795-805.

9. Giguère S, Prescott JF, Dowling PM, eds. Antimicrobial therapy in veterinary medicine. 5th ed. Ames: Wiley Blackwell; 2013. pp 79-103.

10. Papich MG. Pharmacokinetic-pharmacodynamic (PK/PD) modeling and the rational selection of dosage regimes for the prudent use of antimicrobial drugs. Vet Microbiol 2014;171:480-6.

11. Fossum TW. Small animal surgery., 3rd ed. St Louis: Mosby Elsevier; 2007.

12. Chandler EA, Gaskel CJ, Gaskell RM. Feline medicine and therapeutics. $3^{\text {rd }}$ ed. Oxford: Blackwell Publishing; 2004.

13. Guardabassi L, Jensen LB, Kruse H. Guide to antimicrobial use in animals. Oxford: Blackwell Publishing Ltd.; 2008.

14. Papich MG. Saunders handbook of veterinary drugs. Small and large animal. 3rd ed. St. Louis: Elsevier Saunders; 2011. pp 167-169.

15. Plumb DC. Plumbs. Veterinary drug handbook. 7th ed. Ames: WileyBlackwell; 2011. pp 230-233.

16. Lavy E, Ziv G, Shem-Tov M, et al. Pharmacokinetics of clindamycin $\mathrm{HCl}$ administered intravenously, intramus- cularly and subcutaneously to dogs. J Vet Pharm Therap 1999;22:261-5.

17. Batzias GC, Delis GA, Athanasiou LV. Clindamycin bioavailability and pharmacokinetics following oral administration of clindamycin hydrochloride capsules in dogs. Vet J 2005;170: 339-45.

18. Boothe DM. Small animal clinical pharmacology and therapeutics. 2nd ed. St. Louis: Elsevier Saunders; 2012.

19. Brown SA, Dieringer TM, Hunter RP, Zaya MJ. Oral clindamycin disposition after single and multiple doses in normal cats. J Vet Pharm Therap 1989; 12:209-16.

20. Brown SA, Zaya MJ, Dieringer TM, et al. Tissue concentrations of clindamycin after multiple oral doses in normal cats. J Vet Pharm Therap 1990; 13:270-7.

21. Bamberger DM, Foxworth JW, Bridwell DL, et al. Extravascular antimicrobial distribution and the respective blood and urine concentrations in humans. In: Lorian $\mathrm{V}$, ed. Antibiotics in laboratory medicine, 5th ed. Philadelphia: Lippincott Williams \& Wilkins; 2005. pp 719-814.

22. Bennet JV, Brodie JL, Bennet EJ, Kirby WM. Simplified accurate method for antibiotic assay of clinical specimens. Appl Microbiol 1966;14:170-7.

23. Osono T, Umezawa H. Pharmacokinetics of macrolides, lincosamides and streptogramins. J Antimicrob Chemother 1985;16:151-66.

24. Muller-Serieys C, Andrews J, Vacheron F, Cantalloube C. Tissue kinetics of telithromycin, the first ketolide antibacterial. J Antimicob Chemother 2004; 53:149-57. 